\title{
PENGARUH AKUNTABILITAS, KUALITAS PELAYANAN, KEPERCAYAAN MUZAKKI TERHADAP LOYALITAS MUZAKKI
}

\author{
JUMRIANI \\ Fakultas Ekonomi Dan Bisnis Universitas Wijaya Putra \\ imhelcharles96@gmail.com
}

\begin{tabular}{l}
\hline Article Info \\
\hline Keyword: \\
Kualitas Pelayanan, \\
Kepercayaam Muzakki \\
Terhadap Loyalitas \\
Muzzakki \\
\hline
\end{tabular}

Page: $19-29$

\begin{abstract}
Effect of accountability, quality of service, trust Muzakki on loyalty to Muzakki. This research aims to discuss the influence of accountability, quality of service, trust Muzakki on Muzakki loyalty to the institution Muzakki Management Institute Infaq (LMI) Surabaya. The research method is using a quantitative approach. The Unit of analysis in research is to use respondents Muzakki for 100 Muzakki in the area of Surabaya, with the research instrument using the questionnaire in the area of Surabaya, and the method of data analysis using multiple linear regression. The results showed that the simultaneous influence was positive and significant and partiality that accounting was influential towards Muzakki loyalty, the quality of service was influential on Muzakki loyalty, and Muzakki's belief had an effect on Muzakki loyalty.
\end{abstract}

Pengaruh Akuntabilitas, Kualitas Pelayanan, Kepercayaam Muzakki Terhadap Loyalitas Muzakki. Penelitian ini bertujuan untuk membahas pengaruh Akuntabilitas, Kualitas Pelayanan, Kepercayaam Muzakki Terhadap Loyalitas Muzakki pada Lembaga Manajemen Infaq (LMI) Surabaya. Metode penelitian menggunakan Pendekatan Kuantitatif.. Unit analisis dalam penelitian adalah dengan menggunakan responden para muzakki sebanyak 100 muzakki di wilayah Surabaya, dengan instrument penelitian menggunakan kuisioner disebar di wilayah Surabaya, dan metode analisa data dengan menggunakan regresi linier berganda. Hasil penelitian menunjukan bahwa secara simultan berpengaruh positif dan signifikan dan secara parsial bahwa akuntanbilitas berpengaruh terhadap loyalitas muzakki, kualitas pelayanan berpengaruh terhadap loyalitas muzakki, dan kepercayaan muzakki berpengaruh terhadap loyalitas muzakki. 


\section{PENDAHULUAN}

Zakat merupakan salah satu rukun Islam, yang menjadi salah satu unsur pokok berdirinya syariat Islam. Dalam perintah zakat, Nabi Muhammad menetapkan zakat bertingkat bagi mereka yang kaya agar meringankan beban kehidupan umat muslim yang tidak mampu. Saat ini, zakat diterapkan di setiap negara Islam, yang menunjukan bahwa kemudian hari akan ada peraturan pemberian zakat mengenai jumlah zakat. Zakat adalah fardhu 'ain untuk semua umat muslim yang memenuhi syarat. Barangsiapa yang tidak mengeluarkan zakat, maka shalatnya/ibadahnya tidak akan diterima oleh Allah SWT.

Zakat merupakan salah satu bagian dari rukun Islam dan merupakan salah satu bentuk ibadah yang berhubungan dengan kehidupan bermasyarakat (sosial) dan AlQuran juga telah menyebutkan zakat sebanyak 27 kali. Pentingnya zakat menurut agama Islam disebutkan sebagai berikut "Islam didirikan di atas lima dasar: Mengikrarkan bahwa tidak ada Tuhan selain Allah dan Muhammad adalah utusan Allah, mendirikan shalat, menunaikan haji, dan berpuasa pada bulan Romadhon" (H.R. Muttafaq 'alaih). Menurut Al-Qardhwi (Tajang, 2006) bahwa zakat merupakan solusi untuk mengentaskan permasalahan pengangguran, kemiskinan, dan menjadi salah satu usaha pemerataan ekonomi bila sudah dilakukan secara optimal. Oleh sebab itu upaya yang dapat dilakukan dalam rangka merubah dan meningkatkan kehidupan kaum dhuafa adalah dengan memberikan kecukupan dan kemudahan pada sektor ekonomi yang juga menjadi dasar suatu bangsa dapat maju sehingga dapat mewujudkan peningkatan kesejahteraan masyarakat (Bariyah, 2012).

Umat Islam dapat berkembang jika kegiatan sosial kemanusiaan dan kemasyarakatan dapat dikembangkan di seluruh penjuru dunia. Zakat semakin berkembang itu berarti menunjukan arah yang menggembirakan. Keputusan Komisi VIII DPR menjadikan Badan Amil Zakat Nasional sebagai mitra resmi komisi menjadikan zakat semakin besar. Hal tersebut didukung oleh janji komisi yang akan menuntaskan amandemen UU Zakat pada Program Legislatif (Prolegnas). Diharapkan dengan adanya dukungan politik yang lebih besar dapat dioptimalkan oleh BAZNAS dan para stakeholder zakat yang lain, termasuk BAZ/LAZ yang ada dapat meningkatkan peran zakat dalam pembangunan masyarakat di wilayah masing-masing secara signifikan, terutama dalam mengurangi kemiskinan dan kesenjangan pendapatan masyarakat. Pengumpulan dan penyaluran berdasarkan organisasi pengelola zakat adalah sebagai berikut:

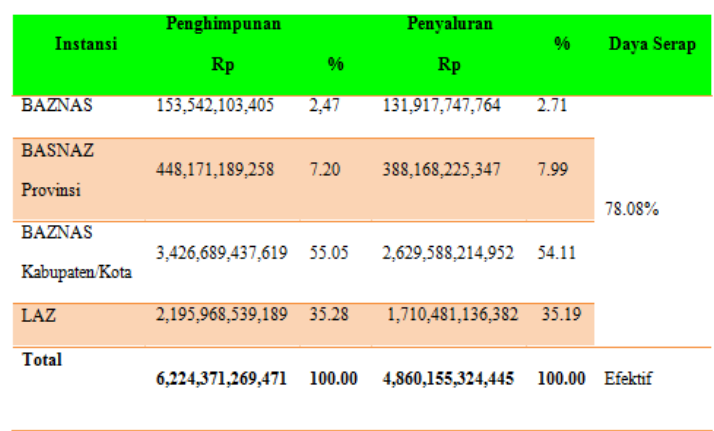

Tabel 1. Penghimpunan dan Penyaluran Zakat Sumber : Statistik Zakat Nasional 2017

Oleh karena itu akan lebih efektif mengurangi kemiskinan yang sudah pasti dan diyakini bahwa akan lebih tepat pada tujuan. Zakat memiliki tarif yang sedikit tetapi tidak pernah berubah-ubah, dikarenakan semua itu telah diatur dalam pandangan Islam/syariah. Zakat dikenakan pada basis yang luas dan meliputi berbagai macam kegiatan ekonomi. Zakat merupakan pajak spiritual yang harus/ wajib dibayarkan oleh setiap umat Muslim dalam keadaan apapun agar penerimaan zakat tetap stabil. Hal ini menjamin keberlangsungan program pengentasan kemiskinan dalam jangka waktu yang 
cukup lama. Muzakki adalah orang yang membayarkan kewajiban zakat atau harta yang ia miliki dan telah mencapai nisab dan haul. Seorang muslim wajib membayar zakat apabila memenuhi kriteria kewajiban mengeluarkan zakat.

Transparansi laporan keuangan yang dianalogikan sebagai suatu sifat dan sikap organisasi pengelola zakat yaitu tabligh, sesuai dengan firman Allah SWT dalam QS Al Maidah ayat 67:

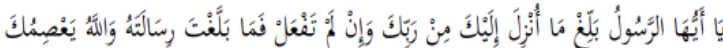

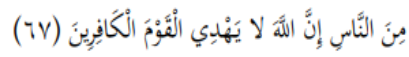

"Hai Rasul sampaikanlah apa yang diturunkan kepadamu dari Tuhanmu dan jika tidak kamu kerjakan apa yang di perintahkan itu, berarti kamu tidak menyampaikan amanat-Nya".

Dalam ayat di atas tersirat bahwa kegiatan pengelola zakat harus memegang teguh aturan Allah, agar selalu memberitahukan segala sesuatu secara benar dan terbuka/transparan, melakukan pekerjaan dengan penuh dedikasi dan kesetiaan yang tinggi serta menjunjung tinggi kejujuran (Dina, 2011).

Hasil survey data BPS (2015) menyimpulkan terdapat peningkatan persentase jumlah penduduk yang kurang mampu pada tahun 2014 sebesar 10,96\% sedangkan pada tahun 2015 menjadi $11,22 \%$. Hal ini terjadi karena adanya peningkatan harga kebutuhan barang pokok yang dibuktikan dengan tingkat inflasi sebesar $3.35 \%$. Berdasarkan data tersebut yang dapat dijadikan sebagai sumber pendanaan optimal dari masyarakat adalah adanya sistem pemberian zakat. Zakat merupakan cara alternatif yang dapat menjadi solusi untuk meningkatkan kemakmuran masyarakat.

Hasil riset Badan Amil Zakat Nasional dan Fakultas Ekonomi dan Manajemen Institut Pertania Bogor (FEM IPB) pada tahun 2011 menunjukkan bahwa potensi zakat nasional mencapai angka
3,40\% dari PDB, atau sekitar 217 triliun rupiah. Berdasarkan data tersebut didapati 99\% potensi zakat nasional belum tersalurkan ke lembaga pengelola zakat.

Hasil penelitian Satrio dan Siswanto (2016) beberapa hal yang menyebabkan ketidakoptimalan jumlah zakat yang terkumpul di antaranya didasari karena adanya ketidaktahuan muzakki untuk kewajiban membayar zakat. Faktor berikutnya adalah adanya keengganan membayar zakat dan faktor ketidakpercayaan masyarakat terhadap Lembaga Pengelola Zakat. Ini menunjukkan pentingnya dan semakin kuatnya tuntutan masyarakat terhadap akuntabilitas lembaga pengelola zakat, sehingga masyarakat dapat memperoleh haknya mengetahui secara menyeluruh atas zakat yang dikelola oleh suatu lembaga penyalur. Penilaian muzakki terhadap lembaga amil zakat beragam sesuai dengan persepsi dan pengalaman masing-masing. Salah satu alasan seorang muslim membayar zakatnya melalui lembaga amil adalah faktor kepuasan (Firdaus et.al. 2012). Salah satu faktor yang dapat menentukan tingkat kepuasan adalah kualitas pelayanan (BAZNAS, 2011). Pengaruh muzakki pada LAZ sangatlah besar, sebab muzakki yang akan terus menerus menyalurkan zakatnya pada LAZ sehingga dapat berpengaruh pada penerimaan zakat lembaga tersebut. Maka LAZ seharusnya berupaya untuk memperhatikan dan mempertahankan para muzakki yang telah mereka miliki sehingga akan terbentuk loyalitas muzakki.

\section{Rumusan Masalah}

1. Bagaimana akuntabilitas, kualitas pelayanan, kepercayaan muzakki dan loyalitas muzakki pada LMI (Lembaga Manajemen Infaq) Surabaya?

2. Apakah ada pengaruh akuntabilitas terhadap loyalitas muzakki pada LMI (Lembaga Manajemen Infaq) Surabaya? 
3. Apakah ada pengaruh kualitas pelayanan terhadap loyalitas muzakki pada LMI (Lembaga Manajemen Infaq) Surabaya?

4. Apakah ada pengaruh kepercayaan muzakki terhadap loyalitas muzakki pada LMI (Lembaga Manajemen Infaq) Surabaya?

5. Apakah ada pengaruh variabel akutanbilitas, kualitas pelayanan, kepercayaan muzakki secara simultan terhadap loyalitas muzakki pada LMI (Lembaga Manajemen Infaq) Surabaya?

\section{Tujuan Penelitian}

Adapun tujuan dari penelitian ini adalah sebagai berikut:

1. Untuk mengetahui dan menjelaskan secara deskriptif akuntabilitas, kualitas pelayanan, kepercayaan muzakki dan loyalitas muzakki di LMI Surabaya.

2. Untuk mengetahui dan menganalisis pengaruh akuntabilitas terhadap loyalitas muzakki di LMI Surabaya.

3. Untuk mengetahui dan menganalisis pengaruh kualitas pelayanan terhadap loyalitas muzakki di LMI Surabaya.

4. Untuk mengetahui dan menganalisis pengaruh kepercayaan muzakki terhadap loyalitas muzakki di LMI Surabaya.

5. Untuk mengetahui dan menganalisis pengaruh variabel akuntabilitas, kualitas pelayanan, kepercayaan muzakki secara simultan terhadap loyalitas muzakki di LMI Surabaya.

\section{KAJIAN PUSTAKA}

\section{Teori Akuntabilitas}

Dalam organisasi public, Krina (2003) menyimpulkan bahwa akuntabilitas berhubungan dengan kewajiban dari institusi pemerintahan maupun aparat yang bekerja di dalamnya untuk membuat kebijakan ataupun aksi yang sesuai dengan nilai yang berlaku atau yang dibutuhkan masyarakat. Akuntabilitas publik menuntut adanya pembatasan tugas yang jelas dan efesien dari aparat birokasi. Prinsip ini menunjukan besarnya tuntutan pelayanan publik sejalan dengan nilai-nilai atau norma-norma eksternal yang dimiliki oleh stakeholder yang berkepentingan pada pelayanan tersebut.

\section{Teori Kualitas Pelayanan}

Kualitas pelayanan adalah suatu tingkat layanan yang berhubungan dengan terpenuhinya harapan dan kebutuhan pelanggan. Artinya pelayanan dikatakan berkualitas jika perusahaan atau lembaga tertentu mampu menyediakan produk atau jasa (pelayanan) sesuai dengan keinginan, kebutuhan maupun harapan pelanggan/ penggunanya (Kotler, 2016).

\section{Teori Kepercayaan Muzakki}

Moorman (1993) mendefinisikan kepercayaan (trust) sebagai kesediaan (willingness) individu untuk menggantungkan dirinya pada pihak lain yang terlibat dalam pertukaran karena individu mempunyai keyakinan (confidence) kepada pihak lain.

\section{Teori Loyalitas Pelanggan}

Pengertian loyal secara harfiah adalah setia. Loyalitas dapat diartikan sebagai kesetiaan. Kesetiaan tersebut diambil tanpa adanya paksaan, timbul dari kesadaran diri sendiri di masa lampau. Gramer dan Brown sebagaimana yang dikutip dalam Utomo (2006:27) menyebutkan bahwa loyalitas merupakan derajat seseorang dalam menunjukan perilaku berulang dari penyedia jasa, memiliki suatu desposisi atau kecenderungan sikap positif terhadap penyedia jasa, dan hanya mempertimbang- 
kan penggunaan penyedia jasa pada saat membutuhkan jasa tersebut.

\section{METODE PENELITIAN}

Berdasarkan tujuan dari penelitian ini maka penelitian ini termasuk ke dalam penelitian explanatory research. Explanatory research adalah perluasan suatu teori struktural yang telah ada sebelumnya dengan cara menguji suatu teori atau hipotesis untuk memperkuat atau bahkan menolak teori atau hipotesis hasil penelitian yang sudah ada sebelumnya. Penelitian ini menjelaskan hubungan tentang hubungan kausal antara variabelvariabel penelitian melalui pengujian hipotesa. Penelitian ini menggunakan pendekatan penelitian kuantitatif, yaitu penelitian yang terstruktur dan menguantifikasi data untuk dapat digeneralisasikan. Menurut Sugiyono (2016) penelitian asosiatif merupakan penelitian yang bertujuan untuk mengertahui pengaruh ataupun hubungan antara dua variabel atau lebih.

\section{Variabel Penelitian}

Dalam penelitian ini variable terikat adalah Loyalitas Muzakki (Y) sedangkan variabel bebas (independent variable) adalah:

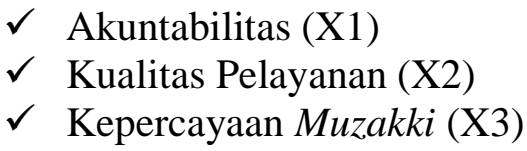

\section{Indikator Variabel Penelitian}

Secara garis besar indikator penelitian dari variabel yang digunakan dalam penelitian ini adalah sebagaimana yang di gambarkan dalam tabel berikut:

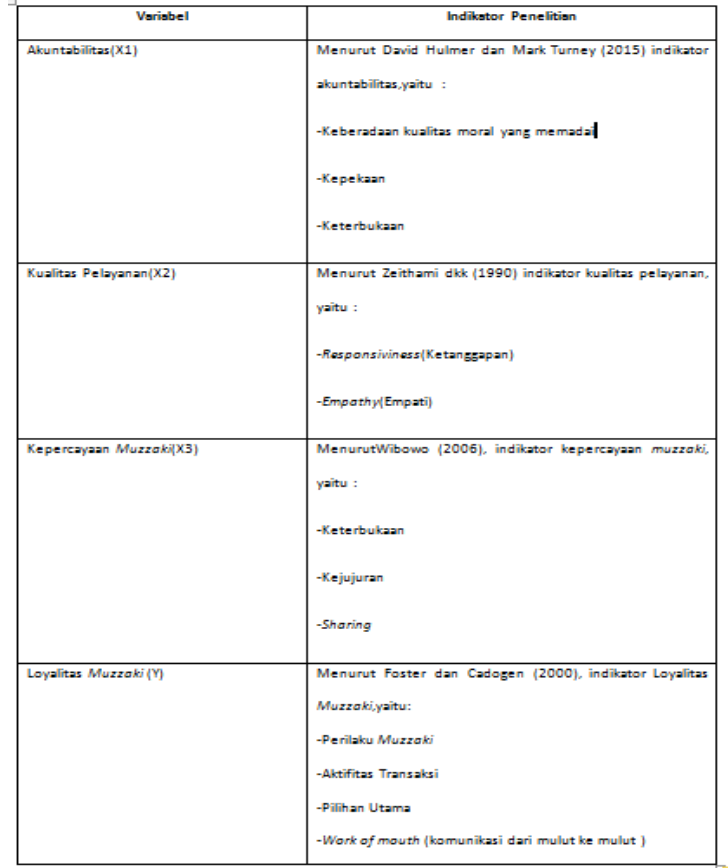

Tabel 2. Variabel dan Indikator Penelitian Sumber: Olahan Penulis Studi pustaka, 2020

\section{Kerangka Konseptual}

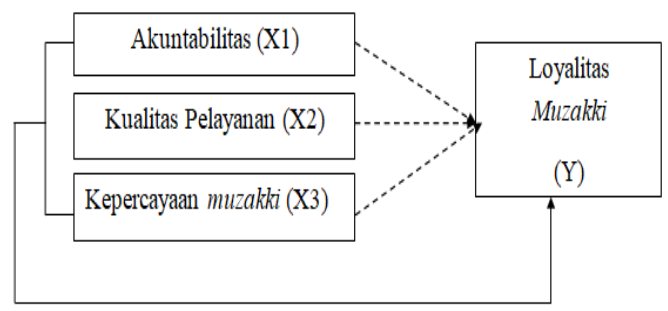

Gambar 1. Kerangka Konseptual Penelitian

\section{Hipotesis Penelitian}

1. Ada pengaruh akuntabilitas terhadap loyalitas muzakki pada LMI Surabaya.

2. Ada pengaruh kualitas pelayanan terhadap loyalitas muzakki pada LMI Surabaya.

3. Ada pengaruh kepercayaan muzakki terhadap loyalitas muzakki pada LMI Surabaya.

4. Ada pengaruh variabel akuntabilitas, kualitas pelayanan, kepercayaan muzakki secara simultan terhadap loyalitas muzakki pada LMI Surabaya.

\section{Lokasi Penelitian}


Lokasi penelitian ini adalah di Lembaga Manajemen Infaq (LMI) Surabaya yang terletak di Gedung Sehati Jl. Barata Jaya XXII No. 20, Surabaya. Penelitian dilakukan selama bulan Mei sampai Juni 2020 .

\section{Populasi, Sampel dan Teknik Sampel}

Populasi dalam penelitian ini adalah muzakki yang menyerahkan dana zakat kepada LMI Surabaya. Teknik sampling yang di gunakan dalam penelitian ini adalah purpose sampling. Kriteria yang digunakan sebagai dasar pengambilan sampel dalam penelitian ini adalah sebagai berikut:

1) Usia 20-50 tahun

Peneliti menggunakan kategori umur dewasa-tua (20-50 tahun) karena dianggap lebih berpengalaman atau senior, sehingga diharapkan lebih banyak memberikan pendapat dalam hal menetapkan keputusan.

2) Pendapatan minimal 1.500 .000

Menurut Fatah (2006), kemampuan ekonomi masyarakat akan menentukan tingkat partisipasinya dalam pembangunan. Masyarakat dengan tingkat kemampuan ekonomi yang tinggi partisipasinya juga tinggi, sedangkan masyarakat dengan tingkat kemampuan ekonomi yang rendah partisipasinya juga rendah, karena mereka akan memilih untuk mecari nafkah sehingga partisipasinya dalam menyalurkan zakat kurang.

Jumlah muzakki yang telah menyalurkan zakatnya di LMI dan sesuai dengan kriteria di atas adalah sebesar 34 muzakki.

\section{Metode Pengumpulan Data dan Instrumen Penelitian}

Sumber data yang digunakan dalam penelitian ini adalah data primer dan data sekunder. Data yang bersifat internal didapat melalui data-data dari pihak LMI
Surabaya dan yang bersifat eksternal didapat melalui sumber-sumber di luar organisasi yang dipublikasikan bank maupun jurnal, buku, internet yang berkaitan dengan variabel-variabel penelitian.

Metode pengumpulan data yang dipakai dalam penelitian ini antara lain kuesioner (angket) dengan menggunakan skala likert, dokumentasi terkait dari jurnal, buku, dokumen internal dan internet.

\section{Teknik Analisis Data}

Penelitian ini menggunakan analisis kuantitatif regresi linear berganda. Formula yang digunakan adalah:

$$
\mathbf{Y}=\boldsymbol{\alpha}+\mathbf{b}_{1} \mathbf{x}_{1}+\mathbf{b}_{2} \mathbf{x}_{2}+\mathbf{b}_{3} \mathbf{x}_{3}+\mathbf{e}
$$

\section{Dimana :}

- Y: Loyalitas Muzakki

- A: Konstanta

- $\mathrm{X}_{1}$ : Akuntanbilitas

- $\mathrm{X}_{2}$ : Kualitas Pelayanan

- $\mathrm{X}_{3}$ : Kepercayaan Muzakki

- $\mathrm{B}_{1}$ : Koefisien regresi untuk variabel Akuntabilitas

- $\mathrm{B}_{2}$ : Koefisien regresi untuk variabel Kualitas Pelayanan

- $\mathrm{B}_{3}$ : Koefisien regresi untuk variabel Kepercayaan Muzakki

- E: standard error

Uji statistik yang digunakan adalah uji statistik $\mathrm{t}$ untuk melihat pengaruh variabel independen secara individual dalam menerangkan variabel dependen. Pengujian dilakukan dengan menggunakan significance level 0,05 ( $\alpha=5 \%)$.

\section{PEMBAHASAN}

Statistik deskriptif digunakan untuk mengetahui rata-rata hitung dan deviasi standart dari pengaruh akuntabilitas, 
kualitas pelayanan, kepercayaan muzakki terhadap loyalitas muzzakki.

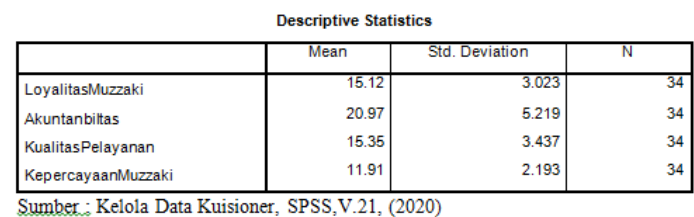

Tabel 3. Uji Diskripsi variabel

\section{Uji Regresi Linier Berganda}

Dalam menganalisis pengaruh akuntabilitas, kualitas pelayanan, kepercayaan muzakki terhadap loyalitas muzzakki, penelitian ini menggunakan analisis regresi linier berganda yang merupakan model analisis kontribusi tersebar dari variabel bebas terhadap variabel terikat. Hasil dari analisis regresi linier berganda dalam penelitian inidapat dilihat dari tabel 4 berikut ini:

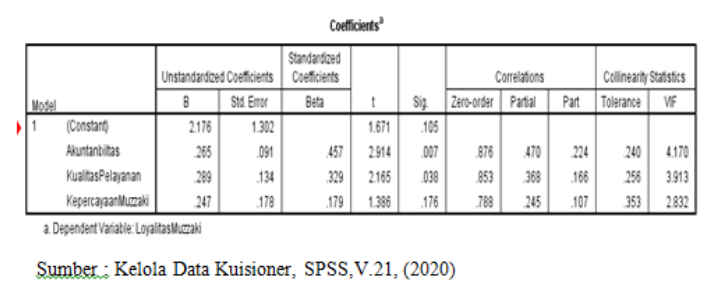

Tabel 4. Regresi Linier Berganda

Berdasarkan tabel di atas dapat dibuat persamaan regresi linier berganda sebagai berikut :

$$
\begin{aligned}
Y= & \alpha+b_{1} X_{1}+b_{2} X_{2}-b_{3} X_{3}+e \\
Y= & 2.172+0,265 X_{1}+0,289 X_{2}+ \\
& 0.247 X_{3}+1.302
\end{aligned}
$$

Persamaan regresi linier berganda di atas dapat dijelaskan sebagai berikut :

1. Konstanta $(\alpha)$ sebesar 2.172 artinya jika akuntabilitas, kualitas pelayanan, kepercayaan muzakki adalah 0 , maka loyalitas muzakki (Y) nilainya adalah 2.172 .

2. Koefisien regresi variabel akuntabilitas (X1) sebesar 0,265 (bernilai positif), artinya akuntabilitas berpengaruh searah dengan loyalitas muzakki. Jika akuntabilitas naik 1 satuan maka loyalitas muzakki (Y) akan meningkat sebesar 0,265.

3. Koefisien regresi variabel kualitas pelayanan (X2) sebesar 0,289 (bernilai positif), artinya kualitas pelayanan berpengaruh searah dengan loyalitas muzakki. Jika kualitas pelayanan naik 1 satuan maka loyalitas muzakki (Y) akan meningkat sebesar 0.289.

4. Koefisien regresi variabel kepercayaan muzakki (X3) sebesar 0,247 (bernilai positif), artinya kepercayaan muzakki berpengaruh searah dengan loyalitas muzakki. Jika kepercayaan muzakki naik 1 satuan maka loyalitas muzakki (Y) akan meningkat sebesar 0.247.

\section{Analisis Koefisien Korelasi}

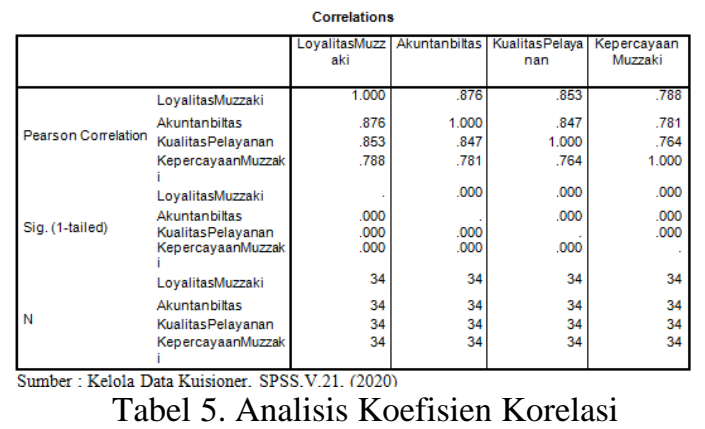

Analisis ini digunakan untuk mengukur tingkat hubungan antara variabel independent $(\mathrm{X})$ dengan variabel dependent (Y). Dalam hal ini mengukur nilai kuat atau lemahnya hubungan dari masing-masing variabel akuntabilitas, kualitas pelayanan, dan kepercayaan muzakki terhadap loyalitas muzakki. Berdasarkan hasil perhitungan dengan menggunakan SPSS Versi 21.0 dapat dilihat pada tabel 5 bahwa nilai koefisien korelasi linear yang dihasilkan antara variabel akuntabilitas adalah sebesar 0,876 , nilai koefisien korelasi linear yang 
dihasilkan variabel kualitas pelayanan adalah sebesar 0,853 , nilai koefisien korelasi linear yang dihasilkan variabel kepercayaan muzakki adalah sebesar 0,788 dan dapat disimpulkan variabel akuntabilitas, kualitas pelayanan, kepercayaan muzakki mempunyai nilai koefisien korelasi yang tinggi dengan variabel akuntanbilitas, dan korelasi yang paling dominan adalah loyalitas muzakki.

\section{Analisis Korelasi Determinan $\left(\mathbf{R}^{\mathbf{2}}\right)$}

Analisis determinasi

digunakan untuk mengetahui persentase sumbangan pengaruh variabel independen (akuntabilitas, kualitas pelayanan, kepercayaan muzakki) secara serentak terhadap variabel dependen (loyalitas muzakki). $\mathrm{R}^{2}$ sama dengan 0 , maka tidak ada sedikit pun persentase sumbangan pengaruh yang diberikan variabel independen terhadap variabel dependen, sebaliknya $\mathrm{R}^{2}$ sama dengan 1 , maka persentase sumbangan pengaruh yang diberikan variabel independen terhadap variabel dependen adalah sempurna.

Menurut Sugiyono (2016), bahwa determinasi berganda adalah jika semua titik terletak tepat pada garis regresi sampel, maka $R^{2}=1$, dalam hal ini dikatakan sesuai secara sempurna. Hasil analisis determinasi diperoleh angka $\mathrm{R}^{2}(R$ Square) sebesar 0,823 atau (82.3\%). Hal ini menunjukkan bahwa persentase sumbangan pengaruh variabel independen terhadap variabel dependen sebesar $95 \%$ atau variasi variabel independen mampu menjelaskan $82.3 \%$ variabel dependen sedangkan sisanya sebesar $17.7 \%$ dipengaruhi atau dijelaskan oleh variabel lain yang tidak dimasukkan dalam model penelitian ini. Hasil analisis determinasi $\left(\mathrm{R}^{2}\right)$ dapat dilihat pada tabel 6 .

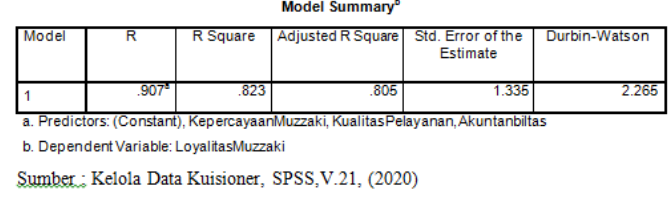

Tabel 6. Hasil Analisis Korelasi Determinan $\left(\mathrm{R}^{2}\right)$

\section{Pengujian Hipotesis \\ Uji F (Uji Simultan )}

Uji $F$ digunakan untuk menguji ada tidaknya pengaruh variabel-variabel independent dengan variabel dependent secara simultan.

1. Apabila $\mathrm{F}$ hitung $>\mathrm{F}$ tabel pada taraf signifikan lebih kecil dari $\alpha=0,05$ maka akuntabilitas, kualitas pelayanan, kepercayaan muzakki secara simultan berpengaruh signifikan terhadap loyalitas muzakki.

2. Apabila $\mathrm{F}$ hitung $<\mathrm{F}$ tabel pada taraf signifikan lebih besar dari $\alpha=0,05$ maka akuntabilitas, kualitas pelayanan, kepercayaan muzakki secara simultan tidak berpengaruh terhadap loyalitas muzakki.

Dari tabel 7 secara empiris nilai hitung F sebesar 46.435 dari masing-masing variabel bebas dan terikat serta memiliki nilai significant 0,000 , bahwa pada nilai significant pada uji $\mathrm{F}$ menunjukan nilai diatas 0,05 atau $5 \%$.

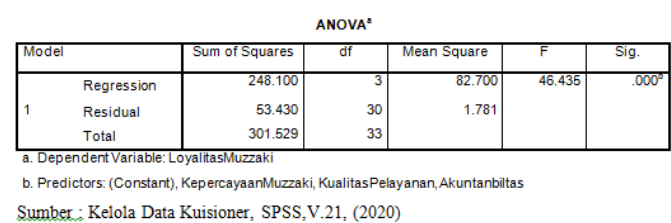

Tabel 7. Uji Simultan (Secara Bersama-sama)

\section{Uji T (Uji secara Individual )}

Uji T dimaksudkan untuk melihat signifikansi pengaruh variabel independen secara parsial terhadap variabel dependen, dengan menganggap variabel lain bersifat konstan secara empiris berarti:

a) Apabila $t$ hitung (bernilai positif) $>t$ tabel pada taraf signifikan lebih kecil 
dari $\alpha=0,05$ berarti variabel bebas mempunyai pengaruh positif dan signifikan terhadap variabel terikat.

b) Apabila $t$ hitung (bernilai positif) $<\mathrm{t}$ tabel pada taraf signifikan lebih besar dari $\alpha=0,05$, berarti variabel bebas tidak mempunyai pengaruh terhadap variabel terikat.

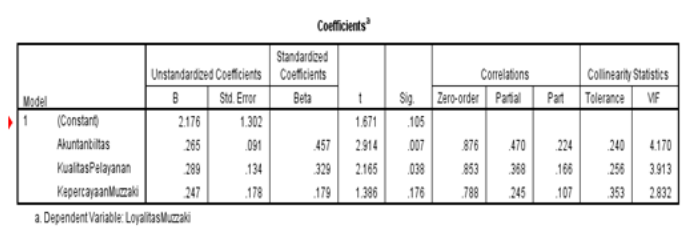

Sumber: Kelola Data Kuisioner, SPSS, V.21, (2020)

Tabel 8. Uji Parsial (Secara Individu)

Dari tabel 8 pada uji parsial dapat diketahui bahwa:

\section{Uji T Akuntanbilitas Terhadap Loyalitas Muzakki}

Diketahui t tabel pada degree of freedom (df) $34-2-1=31$ dengan $\alpha=0,05$ adalah 2,003. Nilai $\mathrm{t}$ hitung variabel Akuntanbilitas sebesar $2.914<\mathrm{t}$ tabel $(2,003)$ dengan nilai signifikansi $(0,005)>$ taraf signifikansi $(0,05)$, maka hipotesis alternatif (Ha) diterima dan menolak hipotesis nul (Ho). Dengan demikian secara parsial akuntanbilitas berpengaruh signifikan terhadap loyalitas muzakki.

\section{Uji T Kualitas Pelayanan Terhadap Loyalitas Muzakki}

Diketahui t tabel pada degree of freedom (df) $34-2-1=31$ dengan $\alpha=0,05$ adalah 2,003. Nilai $t$ hitung variabel kualitas pelayanan sebesar $2.165<\mathrm{t}$ tabel $(2,003)$ dengan nilai signifikansi $(0,005)>$ taraf signifikansi $(0,05)$, maka hipotesis alternatif (Ha) diterima dan menolak hipotesis nul (Ho). Dengan demikian secara parsial kualitas pelayanan berpengaruh signifikan terhadap loyalitas muzakki.

\section{Uji T Kualitas Pelayanan Terhadap Loyalitas Muzakki}

Diketahui t tabel pada degree of freedom (df) $34-2-1=31$ dengan $\alpha=0,05$ adalah 2,003 . Nilai t hitung variabel kepercayaan muzakki sebesar $1.386<\mathrm{t}$ tabel $(2,003)$ dengan nilai signifikansi $(0,005)>$ taraf signifikansi $(0,05), \quad$ maka hipotesis alternatif (Ha) diterima dan menolak hipotesis nul (Ho). Dengan demikian secara parsial kepercayaan muzakki berpengaruh signifikan terhadap loyalitas muzakki.

\section{KESIMPULAN}

1. Dari analisis deskriptif diketahui responden yang berjenis kelamin lakilaki lebih banyak dan responden perempuan lebih sedikit, sebagian besar responden memiliki pendidikan terakhir setingkat Strata (S1), dan terendah adalah setingkat Diploma III. Muzakki didominasi oleh responden yang berusia 21-30 tahun, yang artinya didominasi oleh responden berusia produktif.

2. Variabel akuntabilitas memiliki pengaruh positif dan signifikan terhadap loyalitas muzakki pada LMI Surabaya.

3. Variabel kualitas pelayanan memiliki pengaruh positif dan signifikan terhadap loyalitas muzakki pada LMI Surabaya.

4. Ada pengaruh kepercayaan muzakki memiliki pengaruh positif dan signifikan terhadap loyalitas muzakki pada LMI Surabaya.

5. Variabel akutanbilitas, kualitas pelayanan, kepercayaan muzakki secara simultan mempunyai pengaruh positif dan signifikan terhadap loyalitas muzakki pada LMI Surabaya.

\section{SARAN}

1. Bagi lembaga

Hasil penelitian ini seacara empiris menyumbangkan pemikiran terhadap 
pemecahan masalah yang dikaitkan dengan masalah kualitas pelayanan terhadap loyalitas muzakki melalui kepuasan muzakki dan kepercayaan. Dan diharapkan penelitian ini bermanfaat bagi lembaga pengelolah zakat khususnya Lembaga Manajemen Infaq (LMI) agar dapat mengukur tingkat keberhasilan dan kesuksesannya dalam mengolah dana zakat, infaq dan shodaqoh, dan menjadi salah satu evaluasi dan inovasi baik itu pengumpulan dana maupun penyalurannya.

2. Bagi masyarakat

Dari hasil penelitian ini dapat disarankan agar masyarakat lebih bisa terbuka, mengetahui dan teredukasi dalam hal penyaluran dana zakat, infaq dan shodaqoh.

3. Bagi peneliti lainnya

Disarankan dapat mempertahankan variabel yang sudah peneliti lakukan untuk menambah model penelitian selanjutnya.

\section{DAFTAR PUSTAKA}

Abdullah, Boedi. Metode Penelitian Ekonomi Islam. Bandung: Pustaka Setia, 2014.

A. Qodri, Aziz. Membangun Fondasi Ekonomi Ummat Meneropong Prospek Berkembangmya Ekonomi Islam, Cetakan 1. Yogyakarta: Pustaka Pelajar, 2004.

Baznas. Program BAZNAS, 2014.

Ghazali dan Latan. "Partial Least Squares: Konsep, Teknik dan Aplikasi". Smart PLS M3. Yogyakarta: Pustaka Pelajar, 2012.

Handayani, S. D., \& Helmawati, T. "Pengaruh Kualitas Layanan Terhadap Minat Kunjungan Ulang yang Dimediasi oleh Kepuasan Pasien di Klinik Rumah Zakat Yogyakarta”. Jurnal UMY, 2014.
Inayah, Nurul. "Hubungan Kepercayaan, Transparansi, dan Akuntabilitas Terhadap Loyalitas Muzakki Pada Badan Amil Zakat". Activa Jurnal Ekonomi Syariah, 2018.

Maghfiroh, Siti. "Model Manajemen Strategis Pemberdayaan Ekonomi Umat Melalui Zakat, Infaq, Sedekah". Ekonomi Dan Hukum Islam (2), 2015.

Rochim, Muchamad Ainur. Pengaruh Kualitas Jasa Pelayanan Terhadap Kepuasan Dan Kepercayaan Muzakki pada BAZNAS Kabupaten Tulungagung. Skripsi (tidak diterbitkan). Program Sarjana Strata1 IAIN Tulungagung, 2016.

Septiani. D. F. "Pengaruh Transparansi dan Akuntabilitas Terhadap Pengumpulan Dana Zakat, Infaq, Shodaqoh pada LAZ di Surabaya". Jurnal Akuntansi Akrual, 2 (2), 2011.

Sutomo, Mukhamad Najib \& Djohar, Setiadi. "Pengaruh Kualitas Pelayanan Lembaga Amil Zakat (LAZ) Terhadap Kepuasan Dan Loyalitas Muzakki (Studi Kasus LAZ PKPU Yogyakarta)". Aplikasi Bisnis dan Manajemen, 1 (1), 2017.

Saktiandy, D.E. Pengaruh Program Pemberdayaan dan Kualitas Layanan terhadap Kepuasan dan Loyalitas Pembayaran ZIS dalam Membayar Zakat, Infaq dan Shaaqoh di LAZ yang Berkantor Pusat di Surabaya. Tesis. Surabaya: Universitas Airlangga, 2013.

Sugiyono. Metode Penelitian Kuantitatif, Kualitatif, $\mathrm{R} \& \mathrm{D}$. Cetakan ke-23. Bandung: Alfabeta, 2016.

Safitri, Dyah \& Nurkhim, Achmad. Pengaruh Kualitas Pelayanan Terhadap Loyalitas Muzakki Melalui Kepuasan dan Kepercayaan 
Muzakki. Skripsi, Universitas Negeri Semarang, 2019.

Taufik, Azalia Tarafeuati. "Pengaruh Kualitas Layanan Dan Akuntabilitas Pengelolaan Dana Zakat Pada Lembaga Amil Zakat Terhadap Loyalitas Muzakki”. Jurnal Universitas Negeri Surabaya, 2017. 